\title{
ON THE BUTTERFLIES OF PUYANKUTTY FORESTS, KERALA, INDIA
}

\author{
P.R. Arun* and P.A. Azeez \\ Environmental Impact Assessment Division, Sálim Ali Centre For Ornithology and Natural History, Anaikatty, Coimbatore, Tamil Nadu \\ 641108, India \\ *prarun_2@yahoo.co.uk
}

\begin{abstract}
Puyankutty forest of the Idukki District of Kerala has attracted considerable amount of public interest due to a controversial hydroelectric dam proposal. A rapid survey of the butterflies conducted at seven random locations revealed a total of 32 species of butterflies belonging to five families including a few endemic and rare species. The Puyankutty area is currently under severe anthropogenic pressure and minimising these disturbances is important for the long-term survival of specialist butterflies.
\end{abstract}

\section{Keywords \\ Butterflies, Puyankutty}

\section{Introduction}

The butterfly fauna of the southern part of the Indian peninsula is very rich and diverse compared to other parts of the peninsula due to the availability of diverse habitats, a wide range of altitudinal gradients and associated microclimatic regimes. Butterflies, widely appreciated for their aesthetic value are important as ecological indicators (Chakravarthy et al., 1997) and "flagship taxa" in biodiversity inventories (Lawton et al., 1998). The earliest scientific records on the butterflies of Western Ghats date back to the $18^{\text {th }}$ century records by Linnaeus, Fabricius and Cramer (Gaonkar, 1996). Since then, there have been many studies on butterflies from different parts of the southern India (Fergusson, 1891; Wynter-Blyth, 1944; Mathew \& Rahmathulla, 1993; Gaonkar, 1996; Palot \& Zacharias, 1997; Larsen, 1987, 1988, 1989; Mathew et al., 2000; Sudheendrakumar et al., 2000) including the Western Ghats (Kunte, 1997; Rathinasabapathy, 1998; Rose \& Sharma, 1998; Kunte et al., 1999; Subadradevi \& Davidar 2001; Arun, 2003). However, comprehensive long-term ecological studies to monitor the butterfly population of the area remains a serious lacuna. Such studies are imperative to improve the ecological utility of butterflies as indicator taxa.
The Puyankutty forest, located in Idukki District of Kerala, is a mosaic of moist deciduous, semi-evergreen, low elevation evergreen and riverine forests. Scattered agricultural patches are also present in the vicinity. The area is known for its reed and bamboo resources that have been exploited extensively for many decades now. In the recent past, the proposal for a major hydroelectric project in the area attracted considerable public interest on the ecological importance of the area (Azeez et al., 1999). The present paper is based on a short-term study in and around Pindimedu, the proposed dam site. The survey was conducted mainly along the Puyankutty River and its tributaries. However the present study covered only a very small area of the vast catchment of the Puyankutty River area $\left(\sim 232 \mathrm{~km}^{2}\right)$, which extend roughly between $10^{\circ} 0^{\prime}$ and $10^{\circ} 10^{\prime} \mathrm{N}$ and $76^{\circ} 45^{\prime}$ and $76^{0} 55^{\prime} \mathrm{E}$.

Among the lower invertebrates, butterflies are probably the beststudied group in the Western Ghats forests (Larsen 1987a,b, 1989; Gaonkar, 1996; Arun, 1999). The short duration of the study precluded a complete documentation of the butterfly fauna of the area, and hence the list of species reported in this paper is not a comprehensive checklist. A detailed study covering all the seasons would be required for a comprehensive checklist.

\section{Methodology}

During our visit to Puyankutty forests during the first week of January 1999, a survey of butterflies was undertaken along seven different transects. All the study locations selected were within the close vicinity of the catchment of the Puyankutty River (Figure 1). The butterflies were recorded using standard transect counting method (Ishii, 1993): counted while walking along the selected transect route of $1 \mathrm{~km}$, in each of the seven selected locations during the morning hours between 0830 and $1200 \mathrm{hr}$; all the transects surveyed were segments of existing open paths, such as roads and footpaths; all the butterflies encountered at a radial distance of five meter from the observer were recorded during the counts; butterflies were identified to the species level, except those belonging to the families, Hesperiidae, and Lycaenidae. Seven different transects were surveyed during 


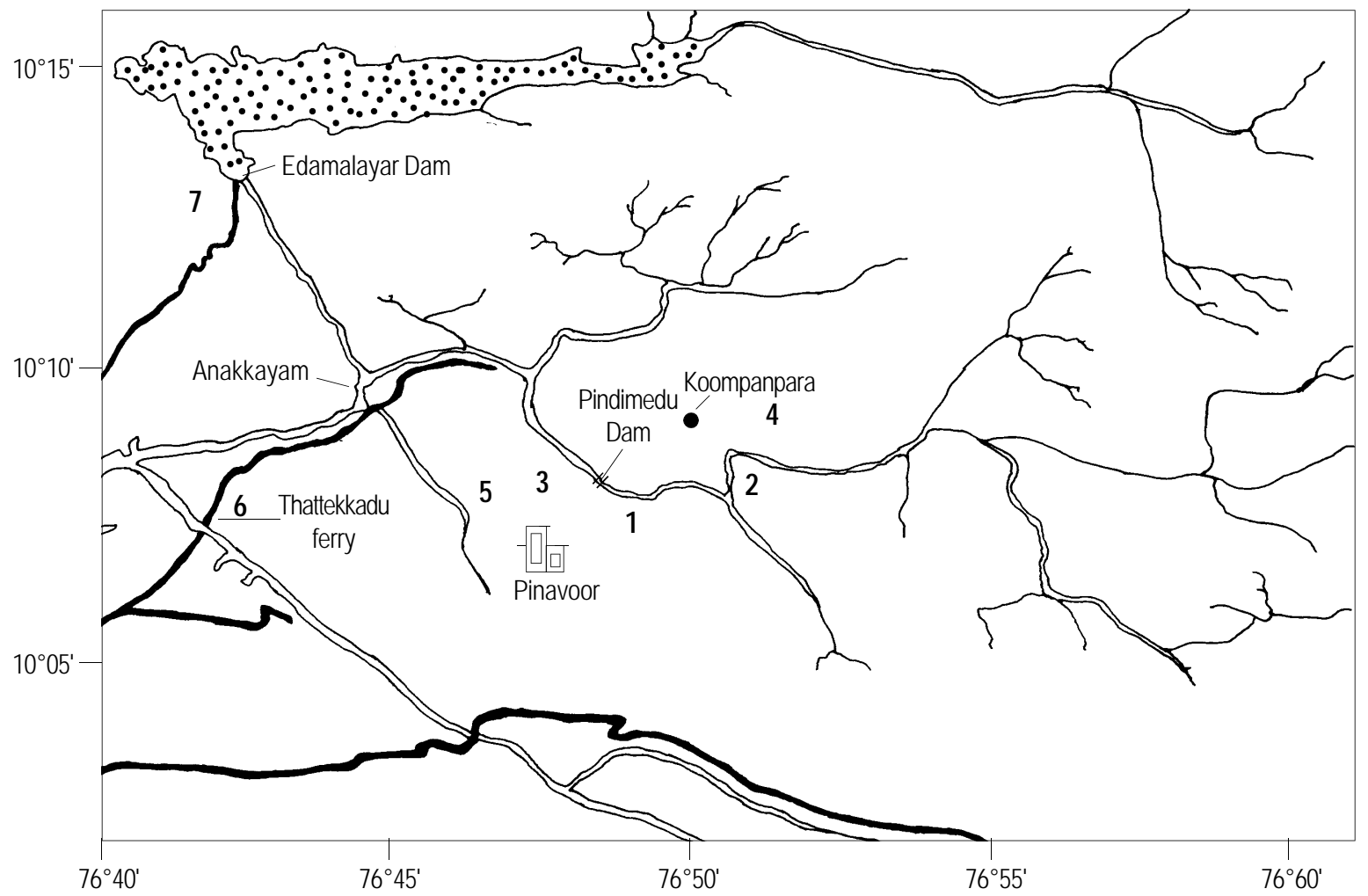

Fig. 1. Location of butterfly transects in the study area

the study (Figure 1). The transects selected for the survey were 1) Tholunada to Damsite, 2) Thuduppiar to Tholunada, 3) Damsite to Puyankutty, 4) Landslide area, 5) Knachery, 6) Thattekkad and 7) Idamalayar. Of these, the first four were located upstream of the proposed dam site at Pindimedu, and the rest in its downstream environs.

The Shannon Weaver Diversity index, H' (Shannon and Weaver 1941) was used to compare diversity between locations

$$
H^{\prime}=-\sum_{i=1}^{s}\left(p_{i} \log _{2} p_{i}\right)
$$

$p_{\mathrm{i}}=$ Proportion of total sample belonging $i^{\text {th }} \mathrm{sp}$.

$\log _{2}=3.322 \log _{10}$

$S=$ Number of species

\section{Observations}

Three hundred and sixty butterflies were encountered along the seven transects surveyed, which included 32 identified species belonging to 26 genera in five families (Table 1). The butterflies belonging to the families Hesperiidae and Lycaenidae could not be identified because of their small size, cryptic colouration and fast movement. However, the abundance of these families was recorded during the counts. The observed abundances of butterflies recorded during the survey is given in Table 1 .

Among the seven locations where survey was conducted, Thuduppiar and Knacherry areas had the highest diversity, abundance and species richness of butterflies, while the Thattekkadu area with dominant teak plantations and sparse undergrowth registered the least abundance of butterflies (Table 2). However, in Thattekkadu, a major reason for recording low diversity and abundance was that the transect count was made during the evening hours.

Nymphalidae is the most abundant and species-rich family in Puyankutty. A total of 257 Nymphalid butterflies belonging to 17 species were observed during the survey. The dominant members of the family were Common Fourring, Common Fivering, Common Sailor, Common Lascar, Chocolate Pansy, Rustic and Tamil Yeoman. The high abundance of satyrid butterflies (Nymphalidae: Satyrinae) observed in the area may probably be attributed to the high abundance of grasses and reeds, which form the major food plants of these butterflies (Wynter-Blyth, 1952; Haribal, 1992). Interestingly, during the survey some variant forms of fiverings and fourrings were also observed, which needs to be further investigated to ascertain their taxonomic status. 
Table 1. Overall abundance of butterflies observed in Puyankutty during the study

\begin{tabular}{|c|c|}
\hline Species name and common name & $\begin{array}{l}\text { No. of } \\
\text { individuals }\end{array}$ \\
\hline \multicolumn{2}{|l|}{ Nymphalidae } \\
\hline Cirrochroa thais Fabricius (Tamil Yeoman) & 15 \\
\hline Cupha erymanthis Sulz (Rustic) & 16 \\
\hline Hypolimnas bolina Linn. (Great Eggfly) & 1 \\
\hline Moduza procris Cramer (Commander) & 1 \\
\hline Neptis hordonia Stoll (Lascar) & 27 \\
\hline Neptis hylas Moore (Sailor) & 42 \\
\hline Parathyma perius Linn. (Sergeant) & 1 \\
\hline Phalanta phalantha Drury (Common Leopard) & 1 \\
\hline Precis iphita Cramer (Chocolate Pansy) & 21 \\
\hline Precis lemonias Linn. (Lemon Pansy) & 1 \\
\hline Danaus genutia Cramer (Striped Tiger) & 1 \\
\hline Euploea core Cramer (Common Crow) & 10 \\
\hline Parantica aglea Moore (Glassy Tiger) & 4 \\
\hline Orsotrioena medus Fabricius (Nigger) & 1 \\
\hline Tirumala limniace Butler (Blue Tiger) & 8 \\
\hline Ypthima baldus Fabricius (Common Five-ring) & 38 \\
\hline Ypthima hubneri Kirby (Common Four-ring) & 69 \\
\hline \multicolumn{2}{|l|}{ Papilionidae } \\
\hline Graphium agammemnon Linn. (Tailed Jay) & 6 \\
\hline Graphium sarpedon Linn. (Common Blue Bottle) & 1 \\
\hline Pachliopta aristolochiae Fabricius (Common Rose) & 4 \\
\hline Pachliopta pandiyana Moore (Malabar Rose) & 6 \\
\hline Papilio dravidarum Wood-Mason (Malabar Raven) & 1 \\
\hline Papilio polymnestor Cramer (Blue Mormon) & 1 \\
\hline Papilio helenus Linn. (Red Helen) & 1 \\
\hline Troides minos Cramer (Southern Bird-wing) & 2 \\
\hline \multicolumn{2}{|l|}{ Pieridae } \\
\hline Catopsilia pomona Fabricius (Common Emigrant) & 9 \\
\hline Delias eucharis Drury (Jezebel) & 2 \\
\hline Eurema hecabe Moore (Grass Yellow) & 23 \\
\hline Pareronia valeria Fabricius (Common Wanderer) & 1 \\
\hline \multicolumn{2}{|l|}{$\underline{\text { Hesperiidae }}^{\star}$} \\
\hline Badamia exclamationis Fabricius (Brown Awl) & 1 \\
\hline Taractrocera ceramas Hewitson (Tamil Grass Dart) & 1 \\
\hline (Unidentified) & 5 \\
\hline \multicolumn{2}{|l|}{ Lycaenidae* $^{*}$} \\
\hline Caleta caleta Hewitson (Angled Pierrot) & 2 \\
\hline (Unidentified) & 37 \\
\hline Total & 360 \\
\hline
\end{tabular}

* All species encountered could not be identified to the species level

The Papilionidae that comprises the swallow-tailed butterflies which has a high degree of endemicity among the butterfly families (Gaonkar, 1996) were represented in the region with eight species, among which three (Malabar Rose, Malabar Raven and Southern Birdwing) are endemic to the region of southern India and Srilanka. Though many papilionids were represented, species abundance was relatively low except for the Malabar Rose (Pachliopta pandiyana) (Table, 1). The Malabar Rose had a relatively higher abundance and wider distribution within the study area.

Five of the total 32 species recorded, namely Malabar Raven (Papilio dravidarum), Malabar Rose (Pachliopta pandiyana), Southern Birdwing (Troides helenus), Jezebel (Delias eucharis) and Tamil Yeoman (Cirrochroa thais) are endemic to South India. Of these, Tamil Yeoman and Malabar Rose were relatively common in the area. The collection of butterflies maintained in the Thattekkad Bird Sanctuary includes many more species collected from the environs of Puyankutty. According to this collection other southern Indian endemics (Wynter-Blyth, 1952) such as Papilio liomedon (Malabar Banded Swallowtail), Idea malabarica (Malabar Tree Nymph) and Kallima philarchus (Blue Oakleaf) are also represented in this region.

\section{Discussion}

Pristine habitats are known to be most ideal for the survival of endemics, and hence the endemic species are generally expected in higher numbers in pristine forest habitats (Spitzer et al., 1993, Hill et al., 1995). Western Ghats is known for many endemic species of butterflies especially those belonging to the Papilionidae family (Gaonkar, 1996). Although, the Puyankutty forest is highly diverse and supports a variety of rare and endemic species, these forests are facing severe anthropogenic pressures. Even in areas with good canopy cover, the under-storey vegetation is highly disturbed, and is cleared off in some areas to facilitate easy transport of reeds extracted from the forest. Encroachments into the forest along the fringes are also rampant. Objective conservation measures are imperative to save these forests from degradation.

Although more than 300 butterflies are reported to be present in the southern Western Ghats (Gaonkar, 1996), many recent studies from other nearby areas such as Parambikulam Wildlife Sanctuary (Sudheendrakumar et al., 2000) and Silent valley National Park (Mathew \& Rahmathulla, 1993) report much less diversity with maximum species richness in the Evergreen habitats (117 species in Parambikulam). The present short-term study could only partially reflect the richness of the butterfly fauna of the Puyankutty region, the much poor species-richness clearly indicates that deteriorating habitat conditions of the area has impoverished the butterfly fauna. Reports show that it is the same case with other forest areas of the region as well. The disturbances caused by the large-scale reed extraction practices, directly affecting the under-storey vegetation and forest regeneration. It has consequently affected the butterflies and other epigeal communities. The minimisation of disturbances is especially important for the survival of endemic butterflies, since these species are the most habitat-specific and has high conservation values (Spitzer et al., 1993). Minimising the anthropogenic disturbances can greatly help in improving the status of habitat specialist butterflies of the Puyankutty forests. 
Table 2. Abundance and diversity of butterflies along different transects

\begin{tabular}{|c|c|c|c|c|c|c|c|}
\hline Transects & Pieridae & Papilionidae & Nymphalidae & Lycaenidae & Hesperidae & Total & Diversity (H') \\
\hline Tholunada to Damsite (T1) & 0 & 2 & 26 & 0 & 1 & 29 & 2.24 \\
\hline Thuduppi ar-Tholunada(T2) & 6 & 2 & 62 & 1 & 0 & 71 & 3.37 \\
\hline Damsite to Puyankutty (T3) & 12 & 0 & 39 & 6 & 0 & 57 & 2.03 \\
\hline Thattekkad (T6) & 0 & 0 & 2 & 7 & 0 & 9 & 0.76 \\
\hline Knachery (T5) & 9 & 12 & 49 & 5 & 3 & 78 & 3.94 \\
\hline Idamalayar (T7) & 3 & 5 & 32 & 10 & 0 & 50 & 3.15 \\
\hline Landslide area (T4) & 5 & 1 & 47 & 10 & 3 & 66 & 3.4 \\
\hline Total & 35 & 22 & 257 & 39 & 7 & 360 & \\
\hline
\end{tabular}

\section{Acknowledgments}

Authors are grateful to the Director, Salim Ali Centre for Ornithology and Natural History, for facilities.

\section{References}

Arun, P.R. (2003). Butterflies of Siruvani forests of Western Ghats, with notes on their seasonality. Zoos' Print Journal 18(2): 1003-1006 Arun, P.R. (1999). Seasonality and abundance of insects with special reference to butterflies (Lepidoptera: Rhopalocera) in a moist deciduous forest of Siruvani, Nilgiri Biosphere Reserve, Tamil Nadu. Ph.D. Thesis, Bharathiar University, Coimbatore (unpublished).

Azeez, P.A., S. Bhupathy, A. Rajasekaran, P.R. Arun, D. Stephen and P. Kannan (1999). Comprehensive Environmental Impact Assessment of the proposed Puyankutty Hydro Electric Project, Kerala. EIA Report, 142pp (unpublished).

Bang, P., P. Dhalstrom and G. Vevers (1972). Collin's Guide to Animal Tracks and Signs. Collins, London.

Chakravarthy, A.K., D. Rajagopal and R. Jagannatha (1997). Insects as bio indicators of conservation in the tropics. Zoos' Print 12: 21- 25. Evans, W.H. (1932). The Identification of Indian Butterflies. Bombay Natural History Society, 454pp.

Fergusson, H.S. (1891). A List of Butterflies of Travancore. Bombay Natural History Society, Bombay, 464pp.

Gaonkar, H. (1996). Butterflies of the Western Ghats, including Sri Lanka. A biodiversity assessment of a threatened mountain system (Unpublished).

Gay, T., I.D. Kehimkar, J. Chandra and P.C. Punetha (1992). Butterflies of India. Oxford University Press.

Haribal, M. (1992). The Butterflies of Sikkim Himalaya and their Natural Histories. Sikkim Nature Conservation Foundation Gangtok, 217pp. Hill, J.K., K.C. Hamer, L.A. Lace and W.M.T. Banham (1995). Effect of selective logging on tropical forest butterflies on Buru, Indonesia. Journal of Applied Ecology 32(4): 754-760.

Ishii, M. (1993). Transect count of butterflies, pp.91-101. In: Decline and Conservation of Butterflies in Japan II.

Kunte, K.J. (1997). Seasonal patterns in butterfly abundance and species diversity in four tropical habitats in Northern Western Ghats. Journal of Biosciences 22: 593-603.

Kunte, K., A. Joglakar, G. Utkarsh and P. Padmanabhan (1999). Patterns of butterfly, bird and tree diversity in the Western Ghats. Current Science 77: 577-586

Larsen, T.B. (1987a). Swallowtail communities in southern India. Papilio International 4: 275-280

Larsen, T.B. (1987b). The butterflies of Nilgiri mountains of southern India (Lepidoptera: Rhopalocera). Journal of the Bombay Natural
History Society 84(1-3): 26- 54, 291- 316, 560-584.

Larsen, T.B. (1989). The butterflies of Nilgiri mountains of southern India (Lepidoptera: Rhopalocera). Journal of the Bombay Natural History Society 85(1): 30- 43

Lawton, J.H., D.E. Bignell, B. Bolton, G.F. Bloemers, P. Eggleton, P.M. Hammond, M. Hodda, R.D. Holts, T.B. Larsen, N.A. Mawdsley, N.E. Stork, D.S. Srivastava and A.D. Watt (1998). Biodiversity inventories indicator taxa and effect of habitat modification in tropical forest. Nature 391: 72-76

Mathew, G. and V.K. Rahmathulla (1993). Studies on the butterflies of the Silent Valley National Park, Kerala, India. Entomon 18: 185- 192. Mathew, G., M. Anto and C.M. Brijesh (2000). Butterflies of Kerala, pp.45-49. In: Sivadasan, M. and K.V. Mohanan (Eds.). Biodiversity and Ecology: Concepts and Facts. University of Calicut, Calicut,

Palot, M.J., G. Mathew and V.J. Zacharias (1997). Butterflies of the Periyar Tiger Reserve, Kerala.

Fergusson, H.S. (1891). A list of butterflies of Travancore. Bombay Natural History Society, Bombay, 464pp.

Rathinasabapathy, B., B.A. Daniel and G. Mathew (1998). Butterflies of Coimbatore Zoological Park site, Anaikatty. Zoos' Print 13(5): 25. Rose, H.S. and N. Sharma (1998). An inventory of Satyridae (Lepidoptera: Rhopalocera) of northwestern India. Zoos' Print 13(11): 29-30.

Shannon, C.E. and W. Weaver (1949). Mathematical Theory of Communication. University of Illinois Press

Spitzer, K., V. Novotny, M. Tonner and J. Leps (1993). Habitat preferences, distribution and seasonality of the butterflies (Lepidoptera, Papilionoidea) in a montane tropical rain forest, Vietnam. Journal of Biogeography 20(1): 109-121.

Subadradevi, M. and P. Davidar (2001). Response of wet forest butterflies to selective logging in Kalakkad Mundanthurai Tiger Reserve. Implications for conservation. Current Science 400-405

Sudheendrakumar, V.V., C.F. Binoy, P.V. Suresh and G. Mathew (2000). Habitat associations of butterflies in the Parambikulam Wildlife Sanctuary, Kerala, India. Journal of the Bombay Natural History Society 97: 193-201.

Wynter-Blyth, M.A. (1944). Butterflies of the Nilgiris. Journal of the Bombay Natural History Society 44: 601-602.

Wynter-Blyth, M.A. (1952). The Butterflies of the Indian Region. Today and Tomorrow Publishers, 523pp. 